\title{
Development of 'Pérola' Pineapple (Ananas comosus vr. comosus) Infructescences Under Organic Fertilization
}

\author{
Jandira Pereira da $\operatorname{Costa}^{1}$, Silvanda de Melo Silva ${ }^{1}$, Alexandre Paiva da Silva ${ }^{1}$, Rejane M. Nunes Mendonça ${ }^{1}$, \\ Djail Santos ${ }^{1} \&$ Dalmo Marcelo de Brito Primo ${ }^{1}$ \\ ${ }^{1}$ Universidade Federal da Paraíba (CCA-UFPB), Campus II, Areia, PB, Brazil \\ Correspondence: Jandira Pereira da Costa, Universidade Federal da Paraíba (CCA-UFPB), Campus II, Areia, PB, \\ CEP: 58397-000, Brazil. E-mail: jandagro2000@yahoo.com.br
}

Received: January 20, 2019

doi:10.5539/jas.v11n13p274
Accepted: July 3, 2019 Online Published: August 15, 2019

URL: https://doi.org/10.5539/jas.v11n13p274

\begin{abstract}
Pineapple (Ananas comosus vr. comosus) plants require balanced nutrition to meet fruit's quality standards for market and consumption. The objective of this research was to evaluate the effects of organic and mineral fertilization on the development of the 'Pérola' pineapple infructescences produced in the Paraíba State, Brazil. The plants were grown under organic fertilization composed by a mixture of cattle manure and poultry litter at 0 , 50,75 and $100 \%$ of the recommended $\mathrm{N}$ rate (RNR) for pineapple cultivation and conventional mineral fertilization. The evaluation of length, diameter, and fresh mass (fruit and crown) of fruit, and crown length was initiated at the $43^{\text {rd }}$ day after floral induction (DAFI). The use organic fertilizer at $100 \%$ of the RNR provided a higher growth rate of fruits as compared to mineral fertilization. In general, the length and diameter of the infructescences evolved rapidly until the $73^{\text {rd }} \mathrm{DAFI}$, corresponding to the first development phase. At the second phase, it was observed an intense growth rate to about the $103^{\text {rd }}$ DAFI, which was followed by a slower growth rate until around the $118^{\text {th }}$ DAFI. In the third and last phase, after the $118^{\text {th }}$ DAFI, the physiological maturity was reached and followed by the commercial maturity at the $133^{\text {rd }}$ DAFI when the pineapple presented from the base $25 \%$ of the fruitlets with yellowish color. Under the experimental conditions herein, the organic fertilization at the level of $75 \%$ RNR promoted a similar growth rate while the $100 \%$ RNR resulted in a greater length and fresh mass of infrutescences compared to the mineral fertilization. Therefore, mixed manure can be a suitable fertilizer alternative for 'Pérola' pineapple's smallholder farming production.
\end{abstract}

Keywords: organic residues, growth pattern, adding value, smallholder farming

\section{Introduction}

Pineapple is a very important fruit crop in Brazil and Pérola cultivar is the most widely grown, especially in the Northeast region (Dantas et al., 2016), due to the greater acceptance by consumers (Meletti et al., 2011). This fruit crop demands a balanced nutrition to reach the market quality standards. In the Brazilian Northeast cultivation of this crop is mostly carried out by smallhold farmers (Brito Neto et al., 2005) for which organic residues can be used as a fertilizer resource. Since production the region's smallhold farming system generally aggregates cattle and poultry production, organic residues are generally available to be used in organic pineapple crops. Research on the potential of organic waste as an exclusive source of crop nutrients has been intensified in recent years (Damatto Júnior et al., 2005; Martelleto et al., 2008; Severo \& Pedrozzo, 2008; Cavalcante et al., 2012; Sarmento et al., 2012; Dantas et al., 2016). However, studies on this potential use in pineapple crop are still incipient (C. H. Liu \& Y. Liu, 2012). In addition, there is no information in the literature on production and postharvest quality of pineapple infructescences grown under mixed organic sources.

The positive affective attitude towards pineapple organic products (Poelman et al., 2008), and a consumers' assumption that organic products increase nutritional properties (Boun \& Prescott, 2002; Detoni et al., 2008), along with its food safety (C. H. Liu \& Y. Liu, 2012) potentiates the organic production of pineapple as an alternative of high added value for the smallhold pineapple systems. In addition, organic farming helps to maintain environmental health by reducing the level of pollution (Martelleto et al., 2008), improving soil's microbiology (Moreira \& Siqueira, 2006) and chemical properties such as supply and retention of nutrients (Menezes \& Salcedo, 2007), reducing nutrient losses into water and the environment (Souto et al., 2005; Wang et al., 2018). 
The potential of using organic sources in fertilization depends on their capability to provide nutrients at the time of greatest crop demand (Pitta et al., 2012; Silva et al., 2014). Thus, the decomposition of the organic matter, with release of organic compounds of low and high molecular mass, will be influenced by the availability of nutrients in the soil, soil and climatic conditions (Souto et al., 2005), and residue quality (C, N, P, S, lignin, cellulose and polyphenols contents). Organic matter is considered an important nutrient source for soil, since its decomposition results in nutrient mineralization and availability (Menezes \& Salcedo, 2007; Pavinato \& Rosolem, 2008).

Fruit size and harvest time are of extreme importance for pineapple crop, since they add value to the fruit. Thus, taking into the account the option of using organic wastes as pineapple fertilizer it is necessary to study the levels and ratio of these nutrient sources to produce fruits that meet the market standards.

As a non-climacteric fruit, pineapple maturation is characterized by specific physiological and biochemical changes resulting in the development of proper varietal characteristics (Martins et al., 2012) and can not be harvested before physiological maturity be reached (Lobo \& Siddiq, 2017). In this direction, the description of growth and maturation curves for 'Pérola' pineapple produced under organic fertilization will enable harvesting at an proper time, allowing the establishment of quality standards for adding value in order to fulfill market demands (Lima, 2011; Martins et al., 2012). Based on that, the aim of this research was to describe how organic and mineral fertilization affect the development of 'Pérola' pineapple infructescences produced under a smallhold farming system in Paraíba State, Northeastern Brazil.

\section{Method}

\subsection{Location}

The experiment was carried out from February 2010 to December 2011 at the Quandu Farm, municipality of Itapororoca, Paraíba State. The experimental area is located at $06^{\circ} 48^{\prime} 27.5^{\prime \prime} \mathrm{S}$ and $35^{\circ} 18^{\prime} 51.5^{\prime \prime} \mathrm{W}$, with an As' type hot and humid tropical climate, with autumn-winter rains (Figure 1), a mean annual temperature ranging from 22 to $26^{\circ} \mathrm{C}$ and presenting dry season, according to the classification of Köppen Geiger (Alvares et al., 2014 ). The soil of the experimental area is classified as Dystrophic Red Yellow Argisol (Ultisol) (Embrapa, 2013).

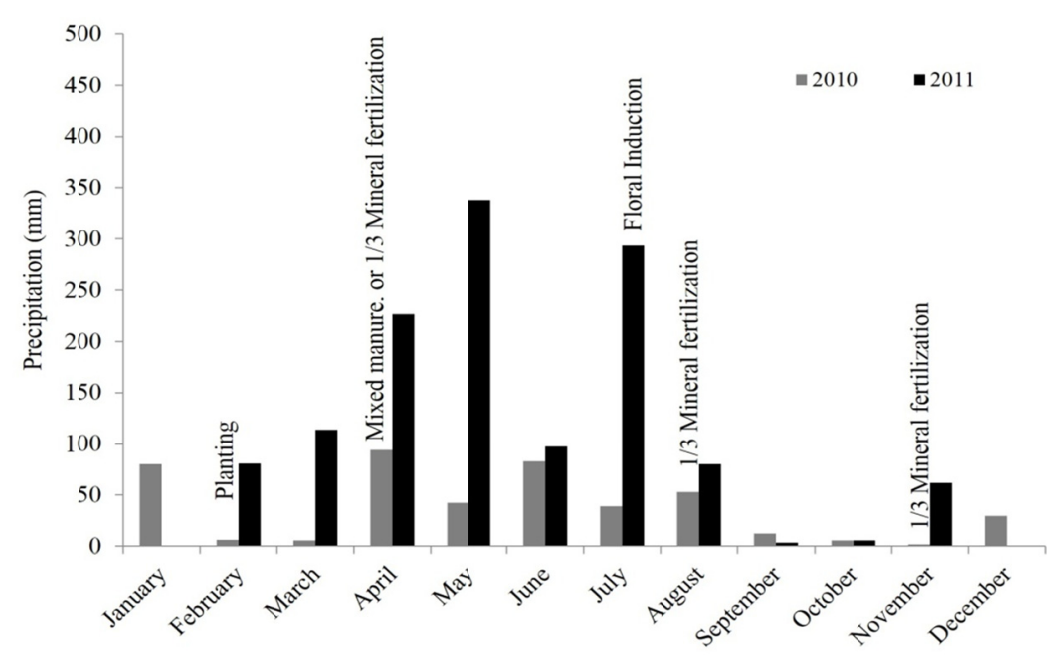

Figure 1. Rainfall precipitation (mm) data during the experimental period in 2010 and 2011 (AESA, 2018)

The definition of the doses of each organic material applied to the field were based on the results of the soil analysis (Table 1), the composition of organic sources used (Table 2), the $\mathrm{N}$ recommendations for this crop (Silva et al., 2009), and on a $\mathrm{N}$ release rate from the organic materials of $50 \%$, as proposed by Silva (2008). In this sense, the following doses were applied: mixed manure (600, 740 and $880 \mathrm{~g} / \mathrm{plant}$ ), corresponding to 50,75 and $100 \%$ of the recommended $\mathrm{N}$ rate (RNR) for this crop (Silva et al., 2009), respectively. These doses were applied in a single rate in each plant, at the $60^{\text {th }}$ day after planting the seedlings.

The experimental plot consisted of a row with 100 plants, and considered the useful area the 60 central plants. 


\subsection{Experimental Design}

The development of the infructescences was evaluated in a completely randomized design, with a $5 \times 7$ factorial scheme, with five treatments and seven evaluation periods, four replications (four plots), and with eight fruits/replication. The treatments evaluated were: T1-Absolute control (without organic and/or mineral fertilization); T2-NPK (9 g N/plant; $2.5 \mathrm{~g} \mathrm{P}_{2} \mathrm{O}_{5} /$ plant; $12 \mathrm{~g} \mathrm{~K}_{2} \mathrm{O} /$ plant $)$; $\mathrm{T} 3-50 \%$, RNR (450 g cattle manure + 150 g poultry litter/plant); T4-75\%, RNR (450 g cattle manure $+190 \mathrm{~g}$ poultry litter/plant); T5-100\%, RNR ( $450 \mathrm{~g}$ cattle manure $+230 \mathrm{~g}$ poultry litter/plant).

For the treatment under conventional fertilization doses of $450 \mathrm{~kg} / \mathrm{ha}$ of $\mathrm{N}, 120 \mathrm{~kg} / \mathrm{ha}$ of $\mathrm{P}_{2} \mathrm{O}_{5}$ and $600 \mathrm{~kg} / \mathrm{ha}$ of $\mathrm{K}_{2} \mathrm{O}$ were applied using urea, triple superphosphate, and potassium chloride, respectively. The doses of $\mathrm{P}$ were applied just before planting, while the doses of $\mathrm{N}$ and $\mathrm{K}$ were applied in the axil of basal leaves in three equal splits at 60, 180 and 270 days after planting.

\subsection{Soil and Organic Sources Analyses}

Table 1. Chemical and physical attributes of soil of the experimental area, from samples collected at the $0-20 \mathrm{~cm}$ depth prior to the installation of the experiments

\begin{tabular}{|c|c|}
\hline Soil chemical attribute & Value \\
\hline $\mathrm{pH}$ in water $1: 2.5$ & 5.5 \\
\hline Soil Organic Matter, $\mathrm{g} / \mathrm{dm}^{3}$ & 8.7 \\
\hline $\mathrm{P}, \mathrm{mg} / \mathrm{dm}^{3}$ & 3.3 \\
\hline $\mathrm{K}^{+}, \mathrm{cmol}_{\mathrm{c}} / \mathrm{dm}^{3}$ & 0.19 \\
\hline $\mathrm{Ca}^{2+}, \mathrm{cmol}_{\mathrm{c}} / \mathrm{dm}^{3}$ & 3.0 \\
\hline $\mathrm{Mg}^{+2}, \mathrm{cmol}_{\mathrm{c}} / \mathrm{dm}^{3}$ & 1.2 \\
\hline $\mathrm{BS}, \mathrm{cmol}_{\mathrm{d}} / \mathrm{dm}^{3}$ & 4.7 \\
\hline $\mathrm{Na}^{+}, \mathrm{cmol}_{\mathrm{c}} / \mathrm{dm}^{3}$ & 0.26 \\
\hline $\mathrm{H}+\mathrm{Al}, \mathrm{cmol}_{\mathrm{c}} / \mathrm{dm}^{3}$ & 11.2 \\
\hline $\mathrm{Al}^{3+}, \mathrm{cmol}_{\mathrm{c}} / \mathrm{dm}^{3}$ & 0.20 \\
\hline CTC efective, $\mathrm{cmol}_{\mathrm{c}} / \mathrm{dm}^{3}$ & 4. 95 \\
\hline CTC total, $\mathrm{cmol}_{\mathrm{C}} / \mathrm{dm}^{3}$ & 15.9 \\
\hline $\mathrm{V}, \%$ & 24.0 \\
\hline Soil physical attribute & Value \\
\hline Coarse sand, $\mathrm{g} / \mathrm{kg}$ & 629 \\
\hline Fine sand, $\mathrm{g} / \mathrm{kg}$ & 248 \\
\hline Silt, $\mathrm{g} / \mathrm{kg}$ & 56 \\
\hline Clay, $\mathrm{g} / \mathrm{kg}$ & 67 \\
\hline Textural class & Sand \\
\hline Bulk density, $\mathrm{g} / \mathrm{dm}^{3}$ & 1.30 \\
\hline Particle density, $\mathrm{g} / \mathrm{dm}^{3}$ & 2.65 \\
\hline Total porosity, $\%$ & 50.9 \\
\hline
\end{tabular}

Table 2. Chemical characterization of the single and mixed (1:1 cattle manure:poultry litter) organic sources, used in this experiment

\begin{tabular}{|c|c|c|c|c|c|c|c|}
\hline Organic Sources & $\mathrm{C}$ & $\mathbf{N}$ & $\mathbf{P}$ & $\mathbf{K}$ & $\mathrm{C} / \mathrm{N}$ & $\mathbf{C} / \mathbf{P}$ & $\mathbf{N} / \mathbf{P}$ \\
\hline & & & & $--g / k \xi$ & 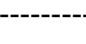 & & ---- \\
\hline Mixed manure & 279.9 & 26.7 & 15.6 & 32.6 & 10.6 & 17.9 & 1.7 \\
\hline Cattle manure & 210.9 & 18.9 & 1.75 & 18.8 & 11.1 & 120.5 & 10.8 \\
\hline Poultry litter & 349 & 34.5 & 1.32 & 46.5 & 10.1 & 264.4 & 26.1 \\
\hline
\end{tabular}

\subsection{Crop Management}

Floral induction was performed at the $17^{\text {th }}$ month with a calcium carbide solution, which was prepared using 12 liters of clean water and $50 \mathrm{~g}$ of calcium carbide all together in a $20 \mathrm{~L}$ capacity vessel, and applied at a rate of 50 $\mathrm{mL}$ in the leaf rosette of each plant. 
During the experimental period, common cultural managements recommended for the crop were used (Rodrigues et al., 2010). Weed control was performed by manual weeding and by herbicide application in the post-emergence period from the fourth month after planting on. The plants were conducted under rainfed conditions, with additional irrigation once a week, during the critical period of rain scarcity between September and December 2010 and 2011 (Figure 1).

\subsection{Evaluations}

The evaluation period started at the $43^{\text {rd }}$ DAFI, with fifteen-day intervals, up to the $133^{\text {rd }}$ DAFI. The fruit length and diameter $(\mathrm{mm})$, fresh mass $(\mathrm{g})$, and crown length $(\mathrm{mm})$ were measured. At each evaluation period 15 fruits were randomly harvested of each plot, totaling 60 fruits per treatment and sent to the laboratory for fruit length and diameter, crown length, using a packymeter, and fresh mass (fruit and crown) using a semi-analytical scale.

\subsection{Statistical Analysis}

Effects of treatments were tested by analysis of variance and the results were submitted to logistic regression of the type: $\mathrm{y}=\mathrm{A} /\left(1+\mathrm{B} \cdot \exp ^{(-\mathrm{k} \cdot t)}\right)$, where $\mathrm{A}=$ maximum developmental value of the observed variable, $\mathrm{B}$ has no biological significance, although it is important to adjust the curve, $\mathrm{k}$ is the development capacity index, and $\mathrm{t}$ is the time (DAFI) by using the $\mathrm{SAS}^{\circledR}$ Program. The logistic regression models were selected according to the parameters $(\mathrm{A}, \mathrm{B}$, and $\mathrm{k})$ for each variable. For the evaluation of the fresh mass, a Tukey test was performed with the four doses of $\mathrm{N}(0,50,75$ and $100 \%)$.

\section{Results and Discussion}

Pineapple length showed a continuous and fast increase from the $43^{\text {rd }}$ to the $103^{\text {rd }}$ DAFI, slowing down after that, in a quadratic pattern, regardless the treatment applied (Figure $2 \mathrm{~A}$ ). However, at the $100 \%$ of the recommended $\mathrm{N}$ rate (RNR), it was noticed a greater increase in fruit's length and diameter than that in pineapple under conventional mineral fertilization, indicating a greater cell expansion during development compared to the other treatments. In turn, fruit measurements did not differ between plants fertilized with $75 \%$ of the RNR and mineral fertilization. The evolution of the length and diameter of the 'Pérola' pineapple infructescence comprised three distinct phases. The first developmental phase began with the clear onset of inflorescence, at the $43^{\text {rd }}$ DAFI, characterized by an initial lag phase and comprosed mostly by cell division (Li et al., 2010; Zhang et al., 2016). This phase was followed by a rapid growth from the $58^{\text {th }}$ DAFI (Figures $2 \mathrm{~A}$ and $2 \mathrm{~B}$ ). The second phase extended from the $58^{\text {th }}$ to the $103^{\text {rd }}$ DAFI, and was reflected by an intense growth phase, that encompassed the period of cellular expansion (Lobo \& Siddiq, 2017; Zhang et al., 2016), which was followed by a tendency to decelerate growth rate until around the $118^{\text {th }}$ DAFI (George et al., 2016). The third stage of development started at approximately the $118^{\text {th }}$ DAFI when physiological maturity was reached, characterized by a very slow down growth rate up to $133^{\text {rd }}$ DAFI, when fruit reached the maximum size and the maturation process was established. At this time, the fruits reached the commercial maturity, characterized in this region of Brazil by a quarter of the yellowish fruit (up to $25 \%$ yellow skin) from the base, which did not differ among the mixed manure and conventional mineral fertilization levels.

Fruit formation results from complex biological processes which begin soon after fertilization (Forlani et al., 2019) and involves a dynamic interplay between phytohormones (McAtee et al., 2013) and availability of essential nutrients (Dantas et al., 2015). These processes include cell division and expansion, accumulation of secondary metabolites, and an increase in carbohydrate biosynthesis (Forlani et al., 2019). In addition, the increase in fresh mass and diameter of pineapple is possibly related to the greater translocation of water, stimulated by the accumulation of solutes in the cells at the beginning of maturation due to the availability of nitrogen ( $\mathrm{Li}$ et al., 2010). The increase in pineapple mass and size during maturation is related to the increase in cell volume, especially of its vacuoles (Lobo \& Siddiq, 2017), which is influenced by the genotype, the source and sink relation, as well as the response of climatic conditions associated with the accumulation of solids and water (Palyath \& Murr, 2008). 

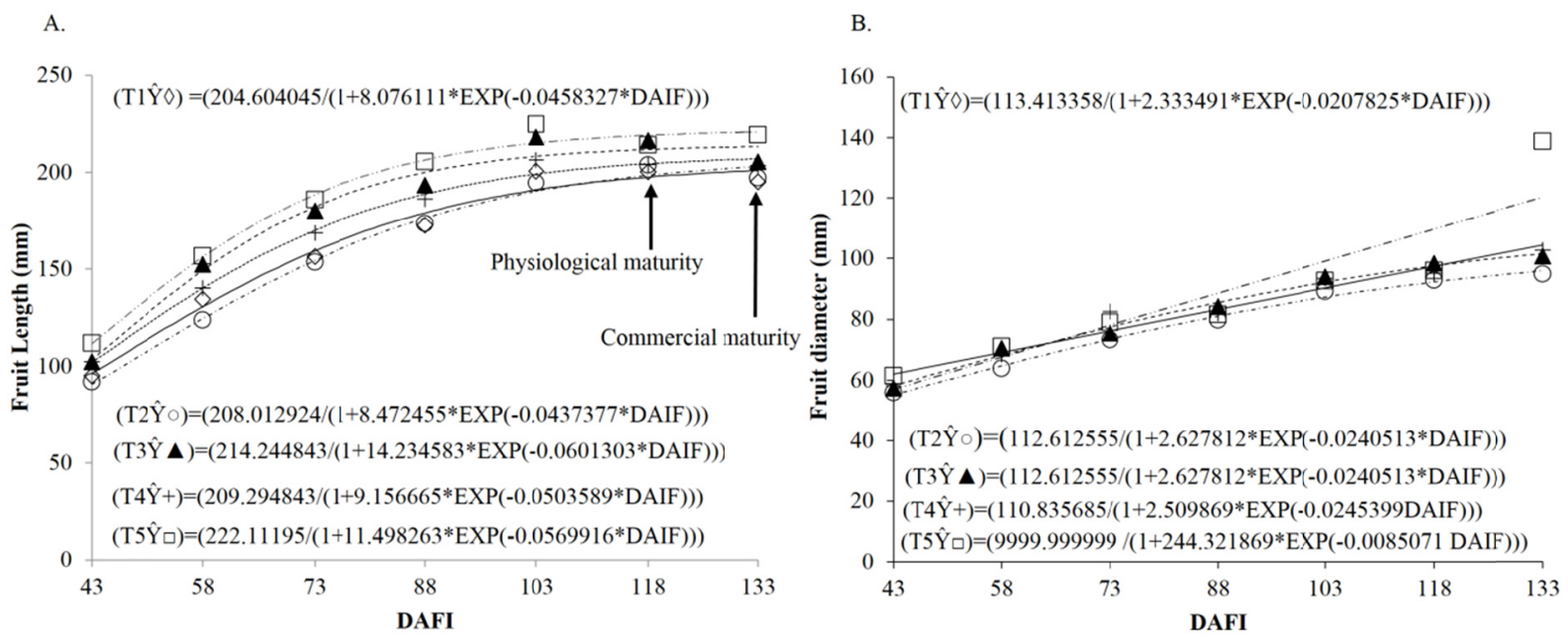

Figure 2. Changes in length (A) and diameter (B) of Pérola pineapple cultivar grown under doses of mixed manure and mineral fertilization from the $43^{\text {rd }}$ day after floral induction (DAFI) $(n=4)$

Note. T1 $\diamond$ (Absolute control-0\%); T2 ○ (NPK); T3 $\Delta$ (50\% RNR); T4 + (75\% RNR) and T5 $\square(100 \%$ RNR). $\mathrm{RNR}=$ Recommended $\mathrm{N}$ rate. The arrows indicate the period in which the physiological and commercial maturities were reached, respectively.

The pattern of cumulative growth herein is in accordance with the one described for 'Sarawak' pineapple, which depicted a sigmoidal growth model for fruit length and diameter (George et al., 2016). This model of development is characterized by an increase in fruit volume provided by the increase in the number and size of the cells, which are initially constituted of protoplasm (Zhang et al., 2016) and, following the growth, formation of vacuoles and accumulation of carbohydrates and other compounds (Li et al., 2010). The primary growth of fruits is due to cell enlargement or cell expansion and can continue until ripening (Palyath \& Murr, 2008).

The fact that the dose of $100 \%$ RNR provided a greater length of the infructescence was explained by Silva et al. (2014) by analyzing the dynamics of the decomposition of the organic nutrient sources (mixed manure) and verified that the decomposition of the poultry litter and its mixing was faster in the first 30 days after application to soil followed by a slower decomposition rate in the subsequent periods. This phenomenon can be explained by its lower contents of lignin-cellulose and hemicellulose (Moreira \& Siqueira, 2006) possibly favoring a greater microbial activity on the poultry litter (Table 1) which presented characteristics of easy and fast decomposition. This implies the availability of nutrients to plants coupled by water availability (Figure 1). Thus, it can be inferred that the poultry litter made available part of its nutrients at the beginning of the crop cycle while the cattle manure did it at the end of the cycle when nutrients were transported for fruit formation (Dantas et al., 2016).

The diameter of the infructescence evolved quadratically (Figure 2B), in such a way that from the $43^{\text {rd }}$ to the $73^{\text {rd }}$ DAFI there was a greater cell expansion, reaching a maximum at the $133^{\text {rd }}$ DAFI, as also reported by George et al. (2016) for Sarawak, and by Zhang et al. (2016), for Comte de Paris pineapple varieties. However, it was also verified that the infructescences from plants treated with mixed fertilization from $100 \%$ of RNR treatment showed larger increases in fruit diameter concomitant with a larger increase in length than in fruits fertilized with NPK.

It should be pointed out that at $133^{\text {rd }}$ DAFI, pineapple infructescences from plants treated with $100 \%$ RNR presented an increase of $40.27 \mathrm{~mm}$ in diameter, corresponding to $40.95 \%$ of increase, as compared to the ones under mineral fertilization, thus resulting in higher pulp yield and, therefore, higher adding value to the product, as reported by C. H. Liu and Y. Liu (2012). The concomitant expansion in diameter and length is a typical change during pineapple development (Palyath \& Murr, 2008; Li et al., 2010).

Regarding the fresh mass, at the $133^{\text {rd }}$ DAFI the mineral fertilization allowed pineapples with a mean fresh mass of $1,413.5 \mathrm{~g}$ and $100 \%$ RNR showed infructescences with $1,510.24 \mathrm{~g}$, which were $6.8 \%$ higher than mineral fertilized fruit (Figure 3A). Fruits from plants treated with organic fertilization showed a progressive increase in the fresh mass parallel to the increase of the RNR, provided by the mixed manure. The release of nitrogen from mixed manure had an additive effect and enhanced the rate of decomposition of this type of material. The release 
of $\mathrm{N}$ and $\mathrm{K}$ was faster during the initial phase. For the release of $\mathrm{P}$, it was reported that for cattle manure it was released by nearly $80 \%$, and by $40 \%$ in poultry litter in the $30^{\text {th }}$ DAA (Silva et al., 2014). This initial decomposition of the poultry litter followed by mixed manure in the first 30 days may have been influenced by the specific decomposition rate of each organic source (Nascimento et al., 2011) along with the climatic conditions (Figure 1), with lower rainfall in the period between January and August 2010.
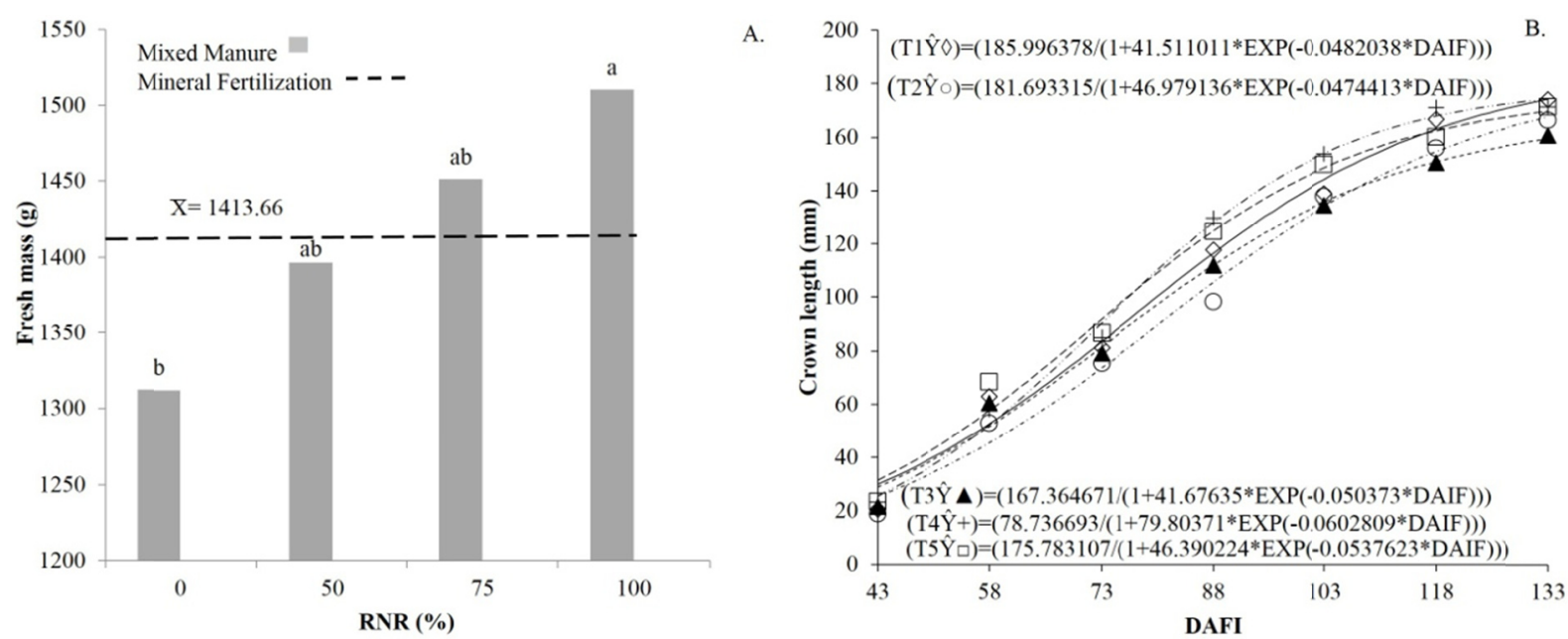

Figure 3. Increases in fresh mass (A) (fruit + crown) under doses of mixed manure and mineral fertilization at the $133^{\text {rd }}$ DAFI and (B) the evolution in the crown length from the $43^{\text {rd }}$ DAFI under mixed manure and mineral fertilization of 'Pérola' pineapple cultivar. Dashed line correspond to the mean fresh mass of pineapple under mineral fertilization $(\mathrm{n}=4)$

Note. T1 $\diamond($ Absolute control-0\%); T2 ○ (NPK); T3 $\Delta$ (50\% RNR); T4 + (75\% RNR) and T5 $\square(100 \%$ RNR). $\mathrm{RNR}=$ Recommended $\mathrm{N}$ rate. $\mathrm{DAFI}=$ Days after the floral induction.

Thus, the lower fresh mass of fruits from plants under mineral fertilization as compared with those under mineral fertilization can be partially explained by the absence of rainfall during the nutrient supply period (Figure 1), so the plants may not have absorbed the quantities of nutrients required for their development and production of fruit with competitive fresh mass to the market. Under these conditions, the absolute control without fertilization reached a much lower mean fresh mass of $1,312.5 \mathrm{~g}$.

The fresh mass for infrustescences under mineral fertilization $(1,413,66 \mathrm{~g})$ did not differ from those obtained from plants fertilized with $75 \%$ RNR $(1,451.50 \mathrm{~g})$, indicating that under the experimental condition this level of mixed manure fulfilled the ferlizer demands for 'Pérola' pineapple crop. Therefore, organic fertilization can be a suitable alternative for pineapple crop. C. H. Liu and Y. Liu (2012) reported that Yueyinaoka pineapple cultivar, of Cayenne group, grown under peanut filter cake and liquid fertilizer, presented fresh mass ranging from 1,384 to $1,598 \mathrm{~g}$ in the range of 'Pérola' pineapple herein.

The crown length gradually evolved up to the $118^{\text {th }}$ DAFI (Figure 3B), when the fruit's physiological maturity started. It can be observed that after the $103^{\text {rd }}$ DAFI, period corresponding to the stabilization of the fruit length, the crown length continued to increase, stabilizing its growth at the beginning of the maturation.

The use of organic fertilizers, as well as the implementation of this production system, whose managements minimize the use of synthetic inputs, reduce soil salinization and improves soil properties (Wang et al., 2018), can be a perspective for a suitable alternative for the smallholder farming pineapple production. Therefore, in the face of favorable impacts on organic pineapple consumers (Poelman et al., 2008), it may be an alternative of high added value for the smallholder pineapple crop of Paraíba and other developing countries where this system predominates.

\section{Conclusion}

Under the experimental conditions herein mixed fertilization (cattle manure + poultry litter) at the dose of $100 \%$ of the recommended nitrogen rate (RNR) provided higher growth rate and fresh mass of 'Pérola' pineapple as compared to mineral fertilization. Growth rate and fresh mass of infructescences of plants fertilized with $75 \%$ 
RNR did not differ from those under mineral fertilization. The physiological maturity of pineapple infructescences was reached at the $118^{\text {th }}$ and the commercial maturity at the $133^{\text {rd }}$ DAFI. All together, mixed organic fertilization may be a suitable alternative to provide the nutritional requirements of Pérola pineapple cultivar. However, these results should be clarified by further studies.

\section{Acknowledgements}

The authors thank to the Banco do Nordeste and CNPq for the financial support, and CAPES for the scholarship granted to the first author.

\section{References}

AESA (Agência Executiva de Gestão das Águas do Estado da Paraíba). (2018). Meteorologia. Retrieved from http://www.aesa.pb.gov.br

Alvares, C. A., Stape, J. L., Sentelhas, P. C., Gonçalves, J. L. M.., \& Sparovek, G. (2014). Köppen's climate classification map for Brazil. Meteorologische Zeitschrift, 22(6), 711-728. https://doi.org/10.1127/ 0941-2948/2013/0507

Brito Neto, J. F., Pereira, W. E., Sá Sobrinho, R. G., Barbosa, J. A., \& Santos, D. P. (2008). Aspectos produtivos da abacaxicultura familiar e comercial no estado da Paraíba. Caatinga, 21(4), 43-50.

Bourn, D., \& Prescott, J. (2002). A comparison of the nutritional value, sensory qualities, and food safety of organically and conventionally produced foods. Critical Reviews in Food Science and Nutrition, 42(1), 1-34. https://doi.org/10.1080/10408690290825439

Cavalcante, L. F., Pereira, W. E., Curvêlo, C. R. S., Nascimento, J. A. M., \& Cavalcante, I. H. L. (2012). Estado nutricional da pinheira sob adubação orgânica. Revista Ciência Agronômica, 43(3), 588. https://doi.org/ 10.1590/S1806-66902012000300022

Damatto Junior, R. E., Villas Boas, R. L., Leonel, S., \& Fernandes, D. M. (2006). Alterações em propriedades de solo adubado com doses de composto orgânico sob cultivo de bananeira Revista Brasileira de Fruticultura, 28(3), 546-549. https://doi.org/10.1590/S0100-29452006000300048

Dantas, A. L., Silva, S. M., Dantas, R. L., Pereira, W. E., Lima, R. P., Mendonça, R. M. N., \& Santos, D. (2015). Influence of combined sources of nitrogen fertilization on quality of cv. Vitória pineapple. African Journal of Agricultural Research, 10(3), 3814-3824. https://doi.org/10.5897/AJAR2015.10182

Detoni, A. M., Clemente, E., \& Fornari, C. (2007). Produtividade e qualidade da uva 'Cabernet Sauvignon' produzida sob cobertura de plástico em cultivo orgânico. Revista Brasileira Fruticultura, 29(3), $530-534$. https://doi.org/10.1590/S0100-29452007000300023

EMBRAPA (Empresa Brasileira de Pesquisa Agropecuária). (2013). Sistema brasileiro de classificação de solos (3rd ed., p. 353). Brasília: Embrapa Solos.

Forlani, S., Masiero, S., \& Mizzotti, C. (2019). Fruit ripening: The role of hormones, cell wall modifications, and their relationship with pathogens. Journal of Exp Botany, 70(11), 2993-3006. https://doi.org/10.1093/ jxb/erz1 12

George, D. S., Razali, Z., \& Somasundram, C. (2016). Physiochemical changes during growth and development of pineapple (Ananas comosus L. Merr. Cv. Sarawak). Journal of Agricultural Science and Technology, 18, 491-503.

Li, Y. H., Zhang, Z., \& Sun, G. M. (2010). Changes in cell number and cell size during pineapple (Ananas comosus L.) fruit development and their relationship with fruit size. Australian Journal of Botany, 58(8), 673-678. https://doi.org/10.1071/BT10225

Lima, A. B. (2011). Qualidade e conservação pós-colheita de abacaxis Pérola e MD-2 sob manejo orgânico e convencional na agricultura familiar (Tese de Doutorado, Agricultura Tropical, UFPB, Brazil).

Liu, C. H., \& Liu, Y. (2012). Influences of organic manure addition on the maturity and quality of pineapple fruits ripened in winter. Journal of Soil Science and Plant Nutrition, 12(2), 211-220. https://doi.org/ 10.4067/S0718-95162012000200002

Lobo, M. G., \& Siddiq, M. (2017). Overview of pineapple production, postharvest physiology, processing and nutrition. In M. G. Lobo, \& R. E. Lobo (Eds.), Handbook of Pineapple Technology Production, Postharvest Science, Processing and Nutrition (Cap. 1, pp. 1-15). Chichester, UK; Hoboken, NJ: John Wiley \& Sons. https://doi.org/10.1002/9781118967355.ch1 
McAtee, P., Karin, S., Schaffer, R., \& David, K. A. (2013). A dynamic interplay between phytohormones is required for fruit development, maturation and ripening. Frontiers of Plant Science, 79(4), 1-7. https://doi.org/10.3389/fpls.2013.00079

Meletti, L. M. M., Sampaio, A. C., \& Ruggiero, C. (2011). Avanços na Fruticultura Tropical no Brasil. Rev. Bras Fruti Revista Brasileira de Fruticultura, 33(SP1), 73-75. https://doi.org/10.1590/S0100-29452011000 500010

Martelleto, L. A. P., Ribeiro, R. L. D., Sudo-Martelleto, M., Vasconcellos, M. A. S., Marin, S. L. D., \& Pereira, M. B. (2008). Cultivo orgânico do mamoeiro 'Baixinho de Santa Amália' em diferentes ambientes de proteção. Revista Brasileira de Fruticultura, 30(3), 662-666. https://doi.org/10.1590/S0100-29452008000 300017

Martins, L. P., Silva, S. M., Silva, A. P., Cunha, G. A. P., Mendonça, R. M. N., Vilar, L. C., ... Lacerda, J. T. (2012). Conservação pós-colheita de abacaxi 'Pérola' produzido em sistemas convencional e integrado. Revista Brasileira de Fruticultura, 34(3), 695-703. https://doi.org/10.1590/S0100-29452012000300007

Menezes, R. S. C., \& Salcedo, I. H. (2007). Mineralização de N após incorporação de adubos orgânicos em um Neossolo regolítico cultivado com milho. Revista Brasileira de Engenharia Ambiental, 11(4), $361-367$. https://doi.org/10.1590/S1415-43662007000400003

Moreira, F. M. S. E., \& Siqueira, J. O. (2006). Microbiologia e bioquímica do solo (2nd ed., p. 729). Universidade Federal de Lavras, Lavras.

Nascimento, A. F., Mendonça, E. S., Leite, F., \& Neves, J. C. L. (2011). Calibration of the Century, APSIM and NDICEA models of decomposition and $\mathrm{N}$ mineralization of plant residues in the humid tropics. Revista Brasileira de Ciência do Solo, 35(3), 917-928. https://doi.org/10.1590/S0100-06832011000300026

Paliyath, G., \& Murr, D. P. (2008). Common Fruits, Vegetables, Flowers, and Their Quality. In G. Paliyath, D. P. Murr, A. K. Handa, \& S. Lurie (Eds.), Postharvest Biology and Technology of Fruits, Vegetables, and Flowers (Cap. 1, pp. 1-7). USA: Wiley-Blackwell.

Pavinato, P. S., \& Rosolem, C. A. (2008). Solo: Decomposição e liberação de compostos orgânicos de resíduos vegetais. (2008). Revisão de literatura. Revista Brasileira de Ciência do Solo, 32(3), 911-920. https://doi.org/ 10.1590/S0100-06832008000300001

Pitta, C. S. R., Adami, P. F., Pelissari, A., Assamann, T. S., Franchin, M. F., Cassol, L. C., \& Sartor, L. R. (2012). Year-round poultry litter decomposition and N, P, K and Ca release. Revista Brasileira de Ciência do Solo, 36(3), 1043-1053. https://doi.org/10.1590/S0100-06832012000300034

Poelman, A., Mojet, J., Lyon, D., \& Sefa-Dedeh, S. (2008). The influence of information about organic production and fair trade on preferences for and perception of pineapple. Food Quality and Preference, 19 (1), 114-121. https://doi.org/10.1016/j.foodqual.2007.07.005

Rodrigues, A. A., Mendonça, R. M. N., Silva, A. P., Silva, S. M., \& Pereira, W. E. (2010). Desenvolvimento vegetativo de abacaxizeiros 'Pérola' e 'Smooth Cayenne' no estado da Paraíba. Revista Brasileira de Fruticultura, 32(1), 126-134. https://doi.org/10.1590/S0100-29452010005000031

Sarmento, J. D. A., Morais, P. L. D., Almeida, M. L. B., Silva, G. G., Sarmento, D. H. A., \& Batalha, S. A. (2012). Qualidade pós-colheita de banana submetida ao cultivo Orgânico e convencional. Revista Brasileira de Produtos Agroindustriais, 14(1), 85-93. https://doi.org/10.15871/1517-8595/rbpa.v14n1p85-93

Severo, L. S., \& Pedrozzo, E. A. (2008). A citricultura orgânica na Região do vale do Caí (Rs): Racionalidade substantiva ou instrumental? Food Quality and Preference, 19, 114-121. https://oi.org/10.1590/ S1678-69712008000200004

Souto, P. C., Souto, J. S., Santos, R. V., Trindade, G. A., \& Souto, L. S. (2005). Decomposição de esterco em diferentes profundidades em área degradada no Semi-árido da Paraíba. Revista Brasileira de Ciência do Solo, 29(1),125-130. https://doi.org/10.1590/S0100-06832005000100014

Silva, A. P., Alvarez, V. H., Souza, A. P., Neves, J. C. L., Novaiz, R. F., \& Dantas, J. P. (2009). Sistema de recomendação de fertilizantes e Corretivos para a cultura do abacaxi-Fertcalc-abacaxi. Revista Brasileira de Ciência do Solo, 33(5), 1269-1280. https://doi.org/10.1590/S0100-06832009000500020

Silva, C. A. (2008). Uso de resíduos orgânicos na agricultura. In G. A. Santos, L. S. Silva, L. P. Canellas, \& F. A. O. Camargo (Eds.), Fundamentos da matéria orgânica do solo: ecossistemas tropicais e subtropicais (pp. 597-624). Porto Alegre: Metrópole. 
Silva, V. B., Silva, A. P., Dias, B. O., Araújo, J. L., Santos, D., \& Franco, R. P. (2014). Decomposição e liberação de N, P e K de esterco bovino e de cama de frango isolados ou misturados. Revista Brasileira de Ciência do Solo, 38(5), 1537-1546. https://doi.org/10.1590/S0100-06832014000500019

Wang, Y., Zhuc, Y., Zhanga, S., \& Wang, Y. (2018). What could promote farmers to replace chemical fertilizers with organic fertilizers? Journal of Cleaner Production, 199(20), 882-890. https://doi.org/10.1016/ j.jclepro.2018.07.222

Zhang, H. N., Sun, W. S., Sun, G. M., Liu, S. H., Li, Y. H., Wu, Q. S., \& Wei, Y. Z. (2016). Phenological growth stages of pineapple (Ananas comosus) according to the extended Biologische Bundesantalt, Bundessortenamt and Chemische Industrie scale. Annals of Applied Biology, 169(2), 311-318. https://doi.org/ 10.1111/aab.12292

\section{Copyrights}

Copyright for this article is retained by the author(s), with first publication rights granted to the journal.

This is an open-access article distributed under the terms and conditions of the Creative Commons Attribution license (http://creativecommons.org/licenses/by/4.0/). 